\title{
MUSLIM FRIENDLY TOURISM AND WESTERN CREATIVE TOURISM: THE CONCEPTUAL INTERSECTION ANALYSIS
}

\author{
Syarifah Hasanah $^{1 *}$, Aizul Nahar Harun ${ }^{2}$ \\ *Corresponding Author \\ ${ }^{1}$ Management of Technology Department, University Technology of Malaysia, Jalan Sultan Yahya Petra, Kampung Datuk \\ Keramat, 54100 Kuala Lumpur, Malaysia. syarifahhasanah137@gmail.com. \\ ${ }^{2}$ Management of Technology Department, University Technology of Malaysia, Jalan Sultan Yahya Petra, Kampung Datuk \\ Keramat, 54100 Kuala Lumpur, Malaysia. aizulnahar.kl@utm.my
}

\begin{abstract}
The present boom and widespread Muslim friendly destinations, extensive research has been carried out on this concept. However, these works have not adequately addressed the issue of creativity, which is widely discussed in the current study of Western tourism literature or so-called creative tourism. This research argued that the current components of Muslim friendly destination are inadequate, particularly in terms of creativity. The aim of this paper is to highlight the concept of creativity embodied in the theoretical and empirical research on Muslim friendly tourism. In order to achieve this, for data collection and analysis, systematic literature review and content or document analysis were used. The findings indicate that this study led the initial stage of understanding the concept of creativity from the perspective of Muslim-friendly tourism. In conclusion, by closely examining the conceptual intersection between Muslim friendly tourism and Western creative tourism, this paper sheds new light on the rarely acknowledged idea of creativity, which is useful for business practitioners in Muslim friendly tourism industry to attract more Muslim market.
\end{abstract}

Keywords: Muslim friendly tourism, creative tourism, conceptual analysis, conceptual intersection.

Received

January 31, 2020
Revised

March 2, 2020
Accepted

March 6, 2020
Published

March 31, 2020

\section{INTRODUCTION}

The Muslim population around the world is rising with highest growth. In reality the growing trend of Muslim-friendly destinations is spreading rapidly in most Muslim countries. As a result, more Muslims are eager to travel to other destinations, either in the majority of Muslim or non-Muslim countries. In the tourism industry itself, the potential of the Muslim market is driven by an increasing interest in the Muslim-friendly tourism industry (Mohsin, Ramli, \& Alkhulayfi, 2016). At the same time, the discussion on Muslim-friendly tourism is gaining popularity in the academic world, such as through journals, conferences and symposium (Faiza Khan, 2017). Interestingly, Pew research center (2015) has projected that by 2030 , the Muslims will make up $26.4 \%$ of the world's total population. Interestingly, Pew Research Center (2015) has estimated that by 2030, Muslims will make up 26.4 percent of the total world population. This significant number is a good indicator for industry practitioners to invest in this potential market.

For many years tourism has been important topics of study in the literature. In the new global economy, tourism has become the main catalyst for economic development. One of the recent new areas for investigation has been the field of creativity. To satisfy tourists with an authentic and memorable experience, the tourism industries should inculcate creative and innovative ideas through activities. 
In addition, the past decade has seen the increase in interest and the blossoming of creative tourism, like in Thailand, the United Kingdom, and New Zealand. Indeed, on the ground, today's trend of tourism has shifted from merely enjoying sightseeing to attaining an authentic experience. In the tourism field, this shift is known as creative tourism. For this reason, players in the Muslim tourism industry should consider adopting this creative tourism concept. This paper argues that the creativity concept of tourism still lacks of discussion in the Muslim tourism context. This paper examines the creativity from the perspective of Muslim tourism literature by highlighting the creative tourism components embedded in Muslim friendly concept. To achieve the objective, the paper will apply the conceptual approach.

Thus far, one has argued that the current components of Muslim friendly destinations are inadequate, notably the creativity element (Darasha, 2016). On the other hand, surprisingly, based on the recent thought by the most prolific scholar on creative tourism, Prof Greg Richards, he points out that to date there is still no literature discussing creative tourism from the Islamic perspective. By focusing on the intersectional concept analysis, the research discussed in this paper has the potential to contribute to the body of knowledge of creative tourism and Muslim friendly tourism, as well as to tourism industry per se. Besides filling in the existing gap, this study presents a crucial initial preliminary investigation stage in identifying the inadequate components of Muslim friendly tourism concept, i.e., the creativity, which is powerful in the Western tourism ecosystem.

\section{LITERATURE REVIEW}

\section{Tourism in Islam}

Islam encourages Muslims to travel to see the beauty of Allah's creation in nature and then to reflect on the greatness of Allah's bountiful blessings upon the humankind. Every place has its uniqueness and different attractions. Not only bestowed with beautiful ranges of mountains, rivers, and lakes, but also race, culture, and customs. Indeed, the contemplation through the lenses of the travellers should bring themselves closer to their creators, as mentioned in the Quran surah Al-Haj verse 46; "Do they not travel through the land, so that their hearts (and minds) may thus learn wisdom and their ears may thus learn to hear? Truly it is not their eyes that are blind, but their hearts which are in their breasts (Ali, 2006). In Islam, the purpose of travelling is to bring more meaning to the travellers' lives.

In Islam, basically, the idea of tourism or travelling has essentially existed for a long time ago (El-gohary, 2016). This is actually an old concept. If it is traced back, it has been in Islam, falls under Hajj (Khan \& Khan, 2016; Mujtaba, 2016; Oktadiana, Pearce, Pusiran, \& Agarwal, 2017). As every Muslim understands, Islam has 5 pillars (arkanul Islam); one of them is Hajj (pilgrimage). Hajj is fulfilling the God's invitation to travel to Macca. And during the implementation of hajj, there are many rules that one must follow and obey. A individual can visit the historical heritage of Islam during the performing hajj, as well as the historical heritage of legacy prophets. Umrah is similar to hajj. It is a requirement for every Muslim to observe the behavior based on Islamic principles during traveling (El-Gohary, 2016; Mujtaba, 2016). 


\section{Western Creative Tourism}

The current knowledge of tourism generally is based on Western. Including creative tourism, it is originally from Western knowledge. Creative tourism is the extension of cultural tourism that has been practiced as mass tourism with no emotional bound and authentic experience with the destination. As a result, cultural tourism was extended to a higher level, leading to the development of creative tourism (Wattanacharoensil and Sakdiyakorn, 2016). The emerging of creative tourism is the demand of tourists who rejected mass and traditional cultural tourism, as well as looking for personal development through courses and meaningful experience by learning and participating (Richards \& Raymond, 2000; S. Tan, Luh, \& Kung, 2014). In addition, creative tourism can also be defined as an enhanced form of cultural tourism that focuses more on the invisible than on the visible heritage (Hassani \& Bastenegar, 2016).

Creative tourism is a prevalent area of importance and research interest due to the creative tourism trend significantly contributes to the countries' GDP. Moreover, it can attract more visitors, create more jobs, bring full of market value, empower the local community, and be a new model for industrial development (OECD, 2014). It comes as no surprise then that how creative tourism differs from other types of tourism and becomes trendy mostly among the developed countries (Richards \& Wilson, 2007). For this reason, creative tourism has significant potential for many future applications in the tourism industry.

\section{How Muslim Tourism Adapt to Western Creative Tourism}

It is myopic and too early to assume that creative tourism has its potential in nonMuslim countries only. Relate to it, and a question has been raised whether creative tourism is also auspicious in the Muslim market landscape. With creativity maelstrom in Western tourism as well as Muslim friendly maelstrom in the Muslim market, indeed both concepts are popular in their domains. Given these points, this study addressed the creative tourism components embedded in Muslim friendly tourism realm. Later, how the industry players can adapt this creative tourism concept into Muslim friendly tourism?

Therefore, the service providers in the tourism industry per se should be more active and creative in providing memorable and authentic tourism products and services. To differentiate from other service providers and attract the potential market of Muslim tourists. It may be plausible to argue that through the practice of Western centric idea of creative tourism, the major problem is whether or not it is compatible with Islamic principles and values, which is very crucial matter. Islamic principles are part and parcel of important aspects that need to be considered in developing creative tourism activities for Muslim travellers. Apart from that, the study of creative tourism in a Muslim context is rarely reported.

\section{METHOD}

The objective of this study is to review Muslim friendly tourism papers, either empirical or theoretical, which highlight the embedded creative tourism concept. This study applied the systematic literature review (SLR) method in filtering and finding the relevant articles on Muslim friendly tourism. 
The systematic literature review (SLR) method (Figure 1) commenced with the search for relevant articles and conducted through the online database search. Specifically, the database search entailed seven reputable publishers, which are Emerald Insight, Oxford Academic Journals, Sage Journals, Science Direct, Springer, Taylor \& Francis Online, and Wiley Online Library.

There are three stages of SLR process in filtering the relevant articles. The first stage is known as the identification phase. To expand the search into a specific study, the use of AND string as a Boolean advance search was utilised immensely in this process. The relevant articles were found using three search strings;

"tourism"

"tourism" AND "Islamic tourism"

"tourism" AND "Islamic tourism" AND "Muslim tourists"

The next phase is known as screening. At this stage, all book/e-books, conference proceedings, book reviews, references, trade publication articles, magazine articles, and newspapers were excluded. Besides that, other articles published before 2007 were also excluded as this research merely focused on publications between the year 2007 and 2018 .

The third phase is called eligibility. At this stage, the titles and the abstracts of the articles were analysed. Whichever irrelevant was removed.

\section{RESULT}

Finally, as the study is at the preliminary stage, so it just focuses on a few research articles, specifically the high indexed journal papers. In the final screening of the systematic literature review method, 13 articles of high indexed journals listed under Web of Science were found relevant to this study.

Table 1. Publication of Muslim Friendly Tourism Research from 2007 until
\begin{tabular}{|c|l|c|c|}
\hline \multirow{2}{*}{ No. } & Database or Publisher & \multicolumn{2}{|c|}{ Keywords } \\
\cline { 3 - 4 } & & Tourism & $\begin{array}{c}\text { Islamic Tourism/ } \\
\text { Muslim Tourist }\end{array}$ \\
\hline 1. & Emerald Insight & 11,421 & 7 \\
\hline 2. & Oxford Academic Journals & 3580 & 2 \\
\hline 3. & Sage Journals & 11,133 & 3 \\
\hline 4. & Science Direct & 34,464 & 25 \\
\hline 5. & Springer & 19,707 & 5 \\
\hline 6. & Taylor \& Francis Online & 49,356 & 32 \\
\hline 7. & Wiley Online Library & 25,784 & 10 \\
\hline
\end{tabular}

Table 1 above describes the publication of Muslim friendly tourism research from the year 2007 until 2018, generated from seven reputable databases; Emerald Insight, Oxford Academic Journals, Sage Journals, Science Direct, Springer, Taylor \& Francis Online, and Wiley Online Library. The findings significantly show there are very few studies on Muslim friendly tourism research. The following discussion focuses on definitions and elements of Muslim friendly tourism, and then the intersection between the booming Muslim friendly tourism concept and the mushrooming Western concept of creative tourism. 
Figure 1. Systematic Literature Review for Muslim Friendly Tourism Research

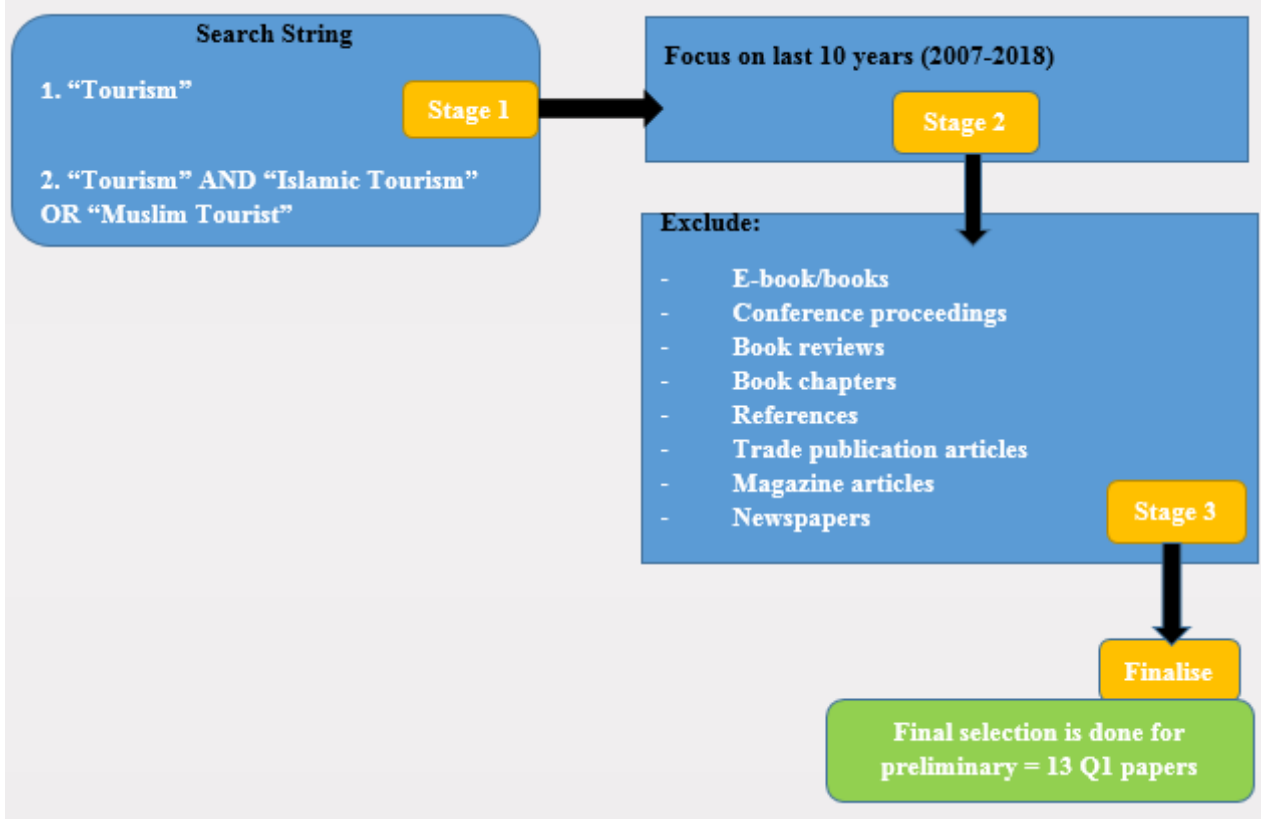

\section{DISCUSSION}

In this section, the discussion revolves around the definitions of Muslim friendly tourism from a few researchers. Then, the discussion continues with the components of Muslim friendly destination as presented by various researchers. Then, it discusses creativity from the tourism perspective, which was implanted in the relevant articles of Muslim friendly tourism found through the systematic literature review method. As this is the preliminary information collection stage, 13 of high indexed journal listed under Web of Science found in this study were the focus of this paper. Preliminary investigation stage is a subsurface exploration to address the issue in this study.

In defining Muslim friendly tourism, the following table presents the various definitions of Islamic tourism by several researchers.

Table 2. Definition of Muslim Friendly Tourism from Various Authors

\begin{tabular}{|c|l|l|}
\hline No. & Author & \multicolumn{1}{c|}{ Definition of Muslim Friendly Tourism } \\
\hline 1. & $\begin{array}{l}\text { (Samori, Md Salleh, \& Khalid, } \\
\text { 2016) }\end{array}$ & $\begin{array}{l}\text { A journey when travellers accomplish his or her role as ibadullah } \\
\text { (servant of Allah), to worship Allah during their travelling. When } \\
\text { embarking a journey, they fulfil their obligation and cling to Islamic } \\
\text { teaching. The journey is not only meaningful for the traveller but also } \\
\text { the traveller will be granted reward by Allah. }\end{array}$ \\
\hline 2. & $\begin{array}{c}\text { (Battour \& Ismail, 2016) } \\
\text { The tourism caters to Muslim, with its product or services are in line } \\
\text { with Islamic principles, regardless the location of destination; either } \\
\text { in Muslim or non-Muslim countries and the motivation of journey } \\
\text { can be religious or general. }\end{array}$ \\
\hline 3. & $\begin{array}{l}\text { (Mohsin et al., 2016) } \\
\text { Halal tourism }\end{array}$ & $\begin{array}{l}\text { Halal tourism is sort of tourism which sticks to Islamic principles, } \\
\text { whereby it enables Muslim to perform their duty to worship Allah } \\
\text { and to eat lawful food. }\end{array}$ \\
\hline 4. & $\begin{array}{l}\text { (Carboni, Perelli, \& Sistu, 2014) } \\
\text { It is a type of tourism in compliance with Islamic teachings and not } \\
\text { restricted to travelling to Muslim countries and with religious motive } \\
\text { only. }\end{array}$ \\
\hline
\end{tabular}




\begin{tabular}{|c|l|l|}
\hline 5. & (Jafari \& Scott, 2014) & $\begin{array}{l}\text { Islamic tourism is defined as a new understanding of so-called } \\
\text { pilgrimage tourism. It is a combination of religious and leisure } \\
\text { tourism in order to replace the hedonic concept of Western tourism. } \\
\text { To meet the needs of Muslims, the products and services offered are } \\
\text { in line with Islamic principles. }\end{array}$ \\
\hline
\end{tabular}

Table 2 above depicts the definition of Muslim friendly tourism by several authors found in high indexed papers listed under Web of Science. Indeed, it can be clearly seen that there are multiple definitions of Muslim friendly destination and a variety of terminologies too. It is important to take note of the term "Muslim friendly tourism" refers to Islamic tourism, halal tourism, Muslim tourism, shariah tourism, and Islamic hospitality. While a variety of terminologies have been used alternatively, this paper followed the term "Muslim friendly tourism" as it is the most common term used by the Standing Committee for Economic and Commercial Cooperation (COMCEC) under the Organisation of Islamic Cooperation (OIC) body.

Moving on, the following table displays the components of Muslim friendly destinations and the Western creative tourism intersections found throughout this literature study. It presents the attributes of Muslim friendly tourism either tangible (physical) or intangible (non-physical), followed by creative tourism qualities embedded in the Muslim friendly tourism attributes.

Table 3. Components of Islamic Tourism/Hospitality

\begin{tabular}{|c|c|c|c|c|}
\hline No. & Author & $\begin{array}{l}\text { Muslim Friendly Tourism } \\
\text { Component } \\
\text { (Intangible (non-physical) }\end{array}$ & $\begin{array}{l}\text { Muslim Friendly Tourism } \\
\text { Component } \\
\text { (Tangible (physical) }\end{array}$ & $\begin{array}{c}\text { Conceptual } \\
\text { Intersection of } \\
\text { Creative } \\
\text { Tourism key } \\
\text { factors; } \\
\text { Co-creation, } \\
\text { Contemplating, } \\
\text { Sightseeing, } \\
\text { Learning, and } \\
\text { Participating }\end{array}$ \\
\hline 1. & $\begin{array}{l}\text { (Samori et } \\
\text { al., 2016) }\end{array}$ & $\begin{array}{l}\text { 1). Easiness in performing worship } \\
\text { to Allah (rukhsah) } \\
\text { 2). Companion in travelling } \\
\text { (mahram); } \\
\text { 3). Magnificent of Allah through } \\
\text { His creation brings more } \\
\text { closeness to Allah }\end{array}$ & $\begin{array}{l}\text { 1). Basic } \\
\text { (halal food, no alcohol, qiblah } \\
\text { direction, prayer mat) } \\
\text { 2). Intermediate } \\
\text { (separation of recreation } \\
\text { facilities for males and females, } \\
\text { Musolla, no adult entertainment, } \\
\text { prayer time, Mosque location) } \\
\text { 3). Extensive: (zakat } \\
\text { counter, Islamic-related } \\
\text { brochures, Islamic tourism } \\
\text { packages) (Muslim } \\
\text { friendly hotels in Malaysia, Md } \\
\text { Salleh, 2014) }\end{array}$ & Contemplating \\
\hline 2. & $\begin{array}{l}\text { (Stephenson, } \\
\text { 2014) }\end{array}$ & $\begin{array}{l}\text { 1). Unity among the Ummah } \\
\text { 2). Hospitality (dhaifa) } \\
\text { 3). Generosity (karam) }\end{array}$ & $\begin{array}{l}\text { 1). Human Resources } \\
\text { 2). Private rooms } \\
\text { 3). Dining and banqueting } \\
\text { facilities } \\
\text { 4). Other public facilities }\end{array}$ & \\
\hline
\end{tabular}




\begin{tabular}{|c|c|c|c|c|}
\hline & & & $\begin{array}{l}\text { 5). Business operation } \\
\text { 6). Hotel operation funding } \\
\text { 7). Promotional strategies } \\
\text { 8). Halal toiletries } \\
\text { 9). Alcohol-free hotel } \\
\text { 10). Halal spa } \\
\text { 11). Shariah compliant resorts } \\
\text { 12). Halal food production } \\
\text { 13). Legitimation of halal } \\
\text { products and muslim-friendly } \\
\text { services } \\
\text { 14). Islamic festivals and events } \\
\text { sector } \\
\text { 15). Halal airlines } \\
\text { 16). Islamic village tourism } \\
\text { 17). Islamic cruises }\end{array}$ & $\begin{array}{c}\text { Contemplating } \\
\text { Sightseeing } \\
\text { Participating }\end{array}$ \\
\hline 3. & $\begin{array}{l}\text { (Battour \& } \\
\text { Ismail, } \\
\text { 2016) }\end{array}$ & & $\begin{array}{l}\text { 1). Halal food } \\
\text { 2). Muslim friendly hotels } \\
\text { 3). Muslim friendly airport }\end{array}$ & No intersection \\
\hline 4. & $\begin{array}{ll}\text { (Mohsin et } & \text { et } \\
\text { al., 2016) } & \end{array}$ & 1). Tawhid-compliance & $\begin{array}{l}\text { 1). Shari'a-compliance: } \\
\text { a). Halal food } \\
\text { b). Aurah/dress code/uniform } \\
\text { (from tourist and hotel staff } \\
\text { c). Shariah compliant hotel (the } \\
\text { uniform of the employee, } \\
\text { prayers room, halal food, not } \\
\text { store alcoholic products, quran, } \\
\text { prayer mat, and Mecca direction } \\
\text { sign, muslim employees, } \\
\text { recognition of Islamic festivals } \\
\text { and holidays) } \\
\text { d). Organizing events like the } \\
\text { halal expo }\end{array}$ & $\begin{array}{c}\text { Contemplating } \\
\text { Sightseeing } \\
\text { Participating }\end{array}$ \\
\hline 5. & $\begin{array}{l}\text { The World } \\
\text { Halal Travel } \\
\text { Summit, } \\
2015\end{array}$ & & $\begin{array}{l}\text { 1). Halal foods } \\
\text { 2). Male and female interactions } \\
\text { 3). Covering aurah } \\
\text { 4). Daily prayers facilities }\end{array}$ & No intersection \\
\hline 6. & $\begin{array}{l}\text { (El-gohary, } \\
2016)\end{array}$ & & $\begin{array}{l}\text { 1). No alcohol } \\
\text { 2). No nightclubs } \\
\text { 3). Halal food } \\
\text { 4). No pork products } \\
\text { 5). Male staff for single male } \\
\text { floors } \\
\text { 6). Female staff for women and } \\
\text { families } \\
\text { 7). Female staff for single } \\
\text { female floors } \\
\text { 8). In-house religious figures } \\
\text { 9). Conservative TV channels } \\
\text { 10). Prayer rooms. } \\
\text { 11). Muslim staff members. } \\
\text { 12). Islamic dressing code for } \\
\text { staff uniforms } \\
\text { 13). Copies of the Quran in each } \\
\text { room } \\
\text { 14). Prayer mats in each room } \\
\text { 15). The direction of Mecca } \\
\text { 16). Separate facilities (such as }\end{array}$ & No intersection \\
\hline
\end{tabular}




\begin{tabular}{|c|c|c|c|c|}
\hline & & & $\begin{array}{l}\text { gyms, swimming pools, etc.) } \\
\text { 17). Gender-segregated prayer } \\
\text { rooms } \\
\text { 18). No human or animal } \\
\text { pictures } \\
\text { 19). Beds and toilet } \\
\text { positioned not to face the } \\
\text { direction of Meccah } \\
\text { 20). Bidets in the bathrooms } \\
\text { 21). Guest suitable dressing } \\
\text { code } \\
\text { 22). Islamic funding. } \\
\text { 23). Hotel and other tourism } \\
\text { companies should follow Zakat } \\
\text { principles }\end{array}$ & \\
\hline 7. & $\begin{array}{l}\text { (Eid \& El- } \\
\text { Gohary, } \\
\text { 2015) }\end{array}$ & $\begin{array}{l}\text { 1). Segregated facilities } \\
\text { 2). Shari'ah-compliant television } \\
\text { channels } \\
\text { 3). Shari'ah-compliant } \\
\text { entertainment tools } \\
\text { 4). Not human depicted art }\end{array}$ & $\begin{array}{l}\text { 1). Prayer facilities } \\
\text { 2). Halal food } \\
\text { 3). Copy of the Holy Qur'an in } \\
\text { hotel rooms } \\
\text { 4). Shari'ah compatible toilets }\end{array}$ & No intersection \\
\hline
\end{tabular}

Table 3 above depicts that 13 high indexed papers, but only seven articles explicitly highlight the attributes/elements/components of Muslim friendly tourism. It could be better to define a creative tourism concept first and then to come out with the key factors or properties of creative tourism properly. According to the most prolific researcher and expert in creative tourism, Prof. Greg Richards, who has reinstituted the concept of creative tourism, he and his colleague, Raymond in the year 2000, defined creative tourism as a destination where tourists can engage with the community through experiencing the potential learning resulting in improving their skills (Termsak, 2014). It means that creative tourism is all about learning, experience, skills, and engagement. In the same vein, other researchers share a similar perspective on the common properties of the creative tourism concept, like 'active participation', 'authentic experiences', 'creative potential development', and 'skills development' (Richards, 2011; S.-K. Tan, Kung, \& Luh, 2013). Equally imperative, Pine and Gilmore (1999) conclude that creative tourism consists of five key factors; co-creation, contemplating, sightseeing, learning, and participating (Limsopitpun, Siriwoharn, \& Laohanan, 2016). Interestingly, the latter properties of creative tourism share certain ideas in common with regards to Muslim friendly tourism concept, notably contemplating (Samori et al., 2016; Stephenson, 2014; Mohsin et al., 2016), sightseeing (Stephenson 2014; Mohsin et al., 2016), and participating elements (Stephenson, 2014; Mohsin et al., 2016). As shown by content analysis in Table 3, the fragmented constructs are contemplating, sightseeing, and participating. It is apparent from this table that very few components of Muslim friendly tourism intersected with creative tourism elements. In this study, these contemplating, participating and sightseeing are the qualities of creative tourism embedded in Muslim friendly tourism literature. 
Figure 2. Conceptual Intersections between Muslim Friendly Tourism and Creative Tourism Notion Based on the Findings

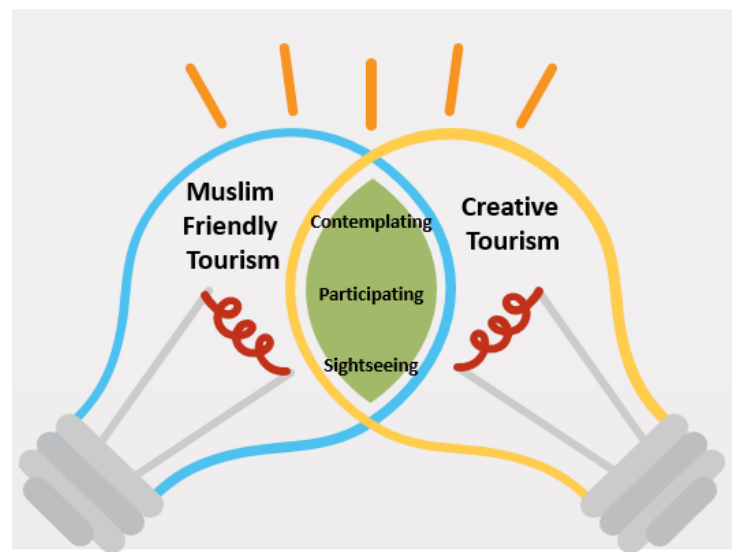

According to the findings, there are three conceptual intersections in this study; contemplating, participating and sightseeing. However, these findings still do not reflect the interpretation of creative tourism itself and also neglect the genuine implementation of creative tourism. In fact, it is skill and experience identified as the gems of creative tourism which are generated from learning exchange (Tiyapiphat, 2017). However, the finding in this study shows that the component of learning through activities is still lacking. Based on the aforementioned intersectional components, researchers come out with the correlation between Muslim friendly tourism and Western creative tourism as presented in the following table 4 .

Table 4. The Intersectional Concept of Muslim Friendly Tourism and Western Creative Tourism

\begin{tabular}{|c|c|c|}
\hline Muslim Friendly Tourism & $\begin{array}{c}\text { Intersectional } \\
\text { Concept }\end{array}$ & Western Creative Tourism \\
\hline $\begin{array}{l}\text { Magnificent of Allah through His } \\
\text { creation brings more closeness to } \\
\text { Allah (Samori et al., 2016). } \\
\text { Generosity (karam) (Stephenson, } \\
\text { 2014). } \\
\text { Tawhid-compliance (Mohsin et al., } \\
\text { 2016) }\end{array}$ & Contemplating & $\begin{array}{l}\text { Internal reflections and interactions with people, } \\
\text { activities, and surroundings which are resulted from } \\
\text { the creative experiences (Limsopitpun et al., 2016) }\end{array}$ \\
\hline $\begin{array}{l}\text { Islamic village tourism (Stephenson, } \\
\text { 2014) } \\
\text { Islamic cruises (Stephenson, 2014) }\end{array}$ & Sightseeing & $\begin{array}{l}\text { Beauty and gorgeous scenery, clean tourists areas, } \\
\text { unique and particular local cultures (Limsopitpun et } \\
\text { al., 2016) }\end{array}$ \\
\hline $\begin{array}{l}\text { Islamic festivals and events sector } \\
\text { (Stephenson, 2014; Mohsin et al., } \\
\text { 2016) }\end{array}$ & Participating & Culinary Tourism Events (Limsopitpun et al., 2016) \\
\hline
\end{tabular}

In the final analysis, these discussions provide the following insights for future research. Islam encourages tourism. One of the creative tourism's constructs or known as creative tourism gem is experiential learning. Islam supports learning, too. This is reflected in 
the first revelation sent down to Prophet Muhammad (may peace and blessing be upon him), i.e., Iqra, which means read. Insightfully, the interpretation of this Quranic verse is to learn in order to acquire wisdom and understanding, which will bring us to the elevation of our eeman (faith). Following this understanding, how to integrate this creative tourism gem into the lacking attributes of Muslim friendly tourism? With reference to these issues, further research is needed to address them comprehensively.

\section{CONCLUSION}

This paper is with the specific condition of using online database searches like Emerald Insight, Oxford Academic Journals, Sage Journals, Science Direct, Springer, Taylor \& Francis Online, and Wiley Online Library. Then, this paper uses a three-stage systematic literature review (SLR) process to study journal papers published in the year of 2007 until 2018, which are related to Muslim friendly tourism. Therefore, as a preliminary study, this paper focuses on Muslim friendly tourism articles published in high indexed journals and simultaneously analyses the creativity concept embedded in that literature. Furthermore, this study highlighted more on the issue of the creativity concept in Muslim friendly tourism context. This article has therefore contributed references to the emerging trend of discussions on Muslim friendly tourism and then drawn together the intersection, specifically, the fragmented construct of Muslim friendly tourism and creative tourism.

Additionally, it should be noted that this paper only uses secondary data to generate the definition and components of Muslim friendly tourism. This study has led the initial stage of understanding the concept of creativity from the perspective of Muslim friendly tourism. By connecting the idea of creative tourism with Muslim friendly tourism, this study has the potential to be a fruitful area for further work. Future studies may be necessary to understand this work in greater detail by using an empirical approach. The results have significant implications for Muslim friendly tourism industry in considering the adaption of creative tourism activities to attract more Muslim travellers.

\section{REFERENCES}

Ali, A. Y. (2006). The Meaning of the Glorious Quran: Text, Translation \& Commentry, 1467.

Battour, M., \& Ismail, M. N. (2016). Halal tourism: Concepts, practises, challenges and future. Tourism Management Perspectives, 19, 150-154. https://doi.org/10.1016/j.tmp.2015.12.008

Carboni, M., Perelli, C., \& Sistu, G. (2014). Is Islamic tourism a viable option for Tunisian tourism? Insights from Djerba. Tourism Management Perspectives, 11(Supplement C), 1-9. https://doi.org/10.1016/j.tmp.2014.02.002

Darasha, Y. (2016). Are Millennials making Muslim-friendly travel redundant?

Eid, R., \& El-Gohary, H. (2015). The role of Islamic religiosity on the relationship between perceived value and tourist satisfaction. Tourism Management, 46, 477-488. https://doi.org/10.1016/j.tourman.2014.08.003

El-gohary, H. (2016). Halal tourism, is it really Halal? Tourism Management Perspectives, 19, 124-130. https://doi.org/10.1016/j.tmp.2015.12.013 
El-Gohary, H. (2016). Halal tourism, is it really Halal? Tourism Management Perspectives, 19, 124-130. https://doi.org/10.1016/j.tmp.2015.12.013

Faiza Khan, M. C. (2017). The " Halalification " of tourism. Journal of Islamic Marketing.

Hassani, A., \& Bastenegar, M. (2016). Components of Spirituality in Creative Tourism. International Journal of Tourism and Spirituality, 1(1).

Jafari, J., \& Scott, N. (2014). Muslim world and its tourisms. Annals of Tourism Research, 44(1), 1-19. https://doi.org/10.1016/j.annals.2013.08.011

Khan, G., \& Khan, F. (2016). An investigation of motivations to engage in eWom among inbound Muslim tourists to Malaysia. International Journal of Business and Globalisation, 16(1), 22-37. https://doi.org/10.1504/IJBG.2016.073623

Limsopitpun, N., Siriwoharn, T., \& Laohanan, S. (2016). An Adaptation Model for Creative Tourism Businesses : A Case Study of Khao Yai Economic Roads and Foreign Tourists. Catalyst, 13(2), 80-88.

Mohsin, A., Ramli, N., \& Alkhulayfi, B. A. (2016). Halal tourism: Emerging opportunities. $\begin{array}{llll}\text { Tourism Management } & \text { Perspectives, }\end{array}$ https://doi.org/10.1016/j.tmp.2015.12.010

Mujtaba, U. (2016). Ramadan: The month of fasting for Muslims, and tourism studies Mapping the unexplored connection. Tourism Management Perspectives, 19, 170-177. https://doi.org/10.1016/j.tmp.2015.11.001

OECD. (2014). Creative tourism: Overview and policy directions. In Tourism and the Creative Economy (pp. 13-31). Paris: OECD Publishing.

Oktadiana, H., Pearce, P. L., Pusiran, A. K., \& Agarwal, M. (2017). Travel career patterns: The motivations of indonesian and malaysian muslim tourists. Tourism, Culture and Communication, 17(4), 231-248. https://doi.org/10.3727/109830417X15072926259360

Richards, G. (2011). Creativity and Tourism The State of the Art. Annals of Tourism Research, 38(4), 1225-1253. https://doi.org/10.1016/j.annals.2011.07.008

Richards, G., \& Raymond, C. (2000). Creative Tourism. ATLAS News, (23), 16-20.

Richards, G., \& Wilson, J. (2007). Tourism , Creativity and Development. Madison Ave, New York: Routledge.

Samori, Z., Md Salleh, N. Z., \& Khalid, M. M. (2016). Current trends on Halal tourism: Cases on selected Asian countries. Tourism Management Perspectives, 19, 131-136. https://doi.org/10.1016/j.tmp.2015.12.011

Stephenson, M. L. (2014). Deciphering "Islamic hospitality": Developments, challenges and opportunities. Tourism Management, 40, 155-164. https://doi.org/10.1016/j.tourman.2013.05.002

Tan, S.-K., Kung, S.-F., \& Luh, D. (2013). A Model of Creative Experience in Creative Tourism. Annals of Tourism Research, 41, 153-174. https://doi.org/10.1016/j.annals.2012.12.002

Tan, S., Luh, D., \& Kung, S. (2014). A taxonomy of creative tourists in creative tourism. Tourism Management, 42, 248-259. https://doi.org/10.1016/j.tourman.2013.11.008

Termsak, S. (2014). Tourism promotion and the use of local wisdom through creative tourism process. International Journal of Business Tourism and Applied Sciences, 2(2), 32-37.

Tiyapiphat, I. (2017). Basics of creative tourism. International Journal of Management and 
Applied Science, 3(5), 148-152.

Wattanacharoensil, W., \& Sakdiyakorn, M. (2016). The Potential of Floating Markets for Creative Tourism: A Study in Nakhon Pathom Province, Thailand. Asia Pacific Journal of Tourism Research, 21(Supplement 1), S3-S29. https://doi.org/10.1080/10941665.2014.998250 